\title{
Bioakumulasi Logam Berat Pb dan Cu terhadap Penaeus merguiensis di Perairan Teluk Kelabat Bagian Dalam
}

\author{
Andini Komalasari ${ }^{*}$, Budi Afriyansyah'1, Muhammad Ihsan² dan \\ Mohammad Agung Nugraha ${ }^{3}$
}

\begin{abstract}
'Program Studi Biologi, Fakultas Pertanian, Perikanan dan Biologi, Universitas Bangka Belitung Kampus Terpadu - Universitas Bangka Belitung, Kab. Bangka, Kepulauan Bangka Belitung, 33172

2Lembaga Pengkajian Pangan, Obat-obatan, dan Kosmetika Majelis Ulama Indonesia, Bangka Belitung

Jl. Depati Hamzah, Bacang, Bukit Intan, Kota Pangkalpinang, Kepulauan Bangka Belitung 33684 3Program Studi Ilmu Kelautan Fakultas Pertanian, Perikanan, dan Biologi, Universitas Bangka Kampus Terpadu - Universitas Bangka Belitung, Kab. Bangka, Kepulauan Bangka Belitung, 33172 Email: andinikomalasari27@gmail.com
\end{abstract}

\section{Abstract \\ Bioaccumulation of $\mathrm{Pb}$ and $\mathrm{Cu}$ Heavy Metals to Penaeus merguiensis in the Waters of Inner Kelabat Bay}

The waters of Kelabat Bay has a wealth of marine resources that is quite important in supporting the economy of Bangka Regency and West Bangka Regency. The purpose of this research was to measure the concentration of heavy metals $\mathrm{Pb}$ and $\mathrm{Cu}$ (sea water, sediment, and Penaeus merguiensis) and measure the ability of Penaeus merguiensis in accumulating heavy metals $\mathrm{Pb}$ and $\mathrm{Cu}$. Heavy metals $\mathrm{Pb}$ and $\mathrm{Cu}$ in Water, sediments and Penaeus merguiensis analyzed using Flame Atomic Absorption Spectrophotometer (Flame AAS). The results showed that concentration of heavy metals in water with an average range of $\mathrm{Pb}(0,1042-0,1748 \mathrm{mg} / \mathrm{L})$ and $\mathrm{Cu}$ $(0,000013-0,000021 \mathrm{mg} / \mathrm{L})$. Average concentration of heavy metals in Pb sediments $(7,15-7,73$ $\mathrm{mg} / \mathrm{kg})$ and $\mathrm{Cu}(0,0016-0,00219 \mathrm{mg} / \mathrm{kg})$. Average concentration of Pb heavy metals in Penaeus merguiensis $(1,34-1,54 \mathrm{mg} / \mathrm{kg})$ and $\mathrm{Cu}(0,0003-0,00045 \mathrm{mg} / \mathrm{kg})$. The average ability of Penaeus merguiensis in accumulating heavy metals $\mathrm{Pb}$ and $\mathrm{Cu}$ is 15,83 to water and 0,19 to sediment. The value of the Bioconcentration Factor is below 250 (FBK <250) so it falls into the low category. Penaeus merguiensis is more exposed to heavy metals dissolved in water than those released from sediment.

Keywords : heavy metals; sediment; spectrophotometer; Inner Kelabat Bay

\begin{abstract}
Abstrak
Perairan Teluk Kelabat memiliki kekayaan sumber daya laut yang cukup penting dalam mendukung perekonomian Kabupaten Bangka dan Kabupaten Bangka Barat. Penelitian ini bertujuan untuk mengukur kandungan logam berat $\mathrm{Pb}$ dan $\mathrm{Cu}$ (air laut, sedimen, dan Penaeus merguiensis) dan mengukur kemampuan Penaeus merguiensis dalam mengakumulasi logam berat $\mathrm{Pb}$ dan $\mathrm{Cu}$. Logam berat $\mathrm{Pb}$ dan $\mathrm{Cu}$ padaair, sedimen dan Penaeus merguiensisdianalisis menggunakan Flame Atomic Absorption Spectrophotometer (Flame AAS). Hasil penelitian menunjukkan bahwa konsentrasi logam berat dalam air dengan kisaran rata-rata $\mathrm{Pb}(0,1042-$ $0,1748 \mathrm{mg} / \mathrm{L})$ dan $\mathrm{Cu}(0,000013-0,000021 \mathrm{mg} / \mathrm{L})$. Kisaran konsentrasi rata-rata logam berat dalam sedimen $\mathrm{Pb}(7,15-7,73 \mathrm{mg} / \mathrm{kg})$ dan $\mathrm{Cu}(0,0016-0,00219 \mathrm{mg} / \mathrm{kg})$. Kisaran konsentrasi rata-rata logam berat $\mathrm{Pb}$ di Penaeus merguiensis $(1,34-1,54 \mathrm{mg} / \mathrm{kg})$ dan $\mathrm{Cu}(0,0003-0,00045 \mathrm{mg} / \mathrm{kg})$. Kemampuan rata-rata Penaeus merguiensis dalam mengakumulasi logam berat $\mathrm{Pb}$ dan $\mathrm{Cu}$ yaitu 15,83 terhadap air dan 0,19 terhadap sedimen. Nilai Faktor Biokonsentrasi tersebut di bawah 250 (FBK< 250) sehingga masuk dalam kategori rendah. Penaeus merguiensis lebih banyak terpapar logam berat yang terlarut dalam air daripada yang terlepas dari sedimen.
\end{abstract}

Kata Kunci: logam berat; sedimen; Spectrophotometere; Teluk Kelabat Dalam 


\section{PENDAHULUAN}

Perairan Teluk Kelabat memiliki kekayaan sumber daya laut yang cukup penting dalam menunjang perekonomian Kabupaten Bangka dan Kabupaten Bangka Barat (Suhendar et al., 2005). Perairan ini memiliki beberapa potensi antara lain sebagai penghasil sumber daya perikanan, tempat wisata bahari, maupun sebagai areal penambangan pasir timah. Teluk Kelabat dibagi menjadi dua bagian, yaitu Teluk Kelabat dalam dan Teluk Kelabat Luar. Teluk Kelabat dalam umumnya didominasi oleh kegiatan perikanan, sedangkan Teluk Kelabat luar lebih mendominasi kegiatan penambangan pasir timah (Hukom, 2010).

Teluk Kelabat bagian dalam memiliki kondisi air yang sangat keruh karena pada areal ini senantiasa menerima masukan air sungai yang bermuara pada bagian teluk (Hukom, 2010). Perairan ini memiliki dua sungai yang cukup besar yaitu Sungai Antan dan Sungai Layang (Simanjuntak, 2007). Kedua sungai tersebut terdapat aktivitas penambangan timah atau disebut Tambang Inkonvensional (TI). Menyebabkan air sungai tersebut senantiasa membawa lumpur yang sangat pekat akibat dari limbah buangan penambangan timah (Hukom, 2010).

Aktivitas penambangan pasir timahmenghasilkan limbah berupa logam berat yang tidak dibutuhkan (non essensial) seperti $\mathrm{Pb}$ dan logam berat yang dibutuhkan (essensial) seperti Cu (Prianto dan Husnah, 2009). Kedua logam tersebut merupakan logam yang masuk ke dalam golongan logam yang memiliki toksisitas tinggi. Logam tersebut dapat menimbulkan efek toksik di dalam tubuh jika dalam jumlah yang melebihi baku mutu yang telah ditetapkan. Peningkatan kadar logam berat dalam air laut akan diikuti oleh peningkatan kadar logam berat dalam sedimen dan tubuh biota laut (Selpiani et al., 2015) terutama dari jenis Crustacea.

Pada ekosistem perairan, biota perairan yang mempunyai peranan paling tinggi dalam penyerapan logam berat yaitu dari jenis Crustacea. Crustacea selalu mencari makan di dasar air yakni pada sedimen. Sedimen mengandung banyak partikel-partikel padatan yang terendap berupa pasir dan lumpur serta logam berat sebagai akibat proses pengendapan di perairan. Hal inilah yang menyebabkan Crustacea dapat terpapar dan mengakumulasi logam berat (Novianto et al., 2012 ).

Jenis Crustacea yang dikonsumsi masyarakat Bangka Belitung salah satunya yaitu Penaeus merguiensis. Penaeus merguiensis banyak dikonsumsi oleh masyarakat dari berbagai lapisan karena memiliki nilai gizi yang tinggi antara lain mengandung beberapa mineral seperti Kalsium, Fosfor, Besidan Vitamin (Budiarti et al., 2010). Menurut Said (2009), udang memiliki kemampuan bias bertahan hidup dan berkembangbiak di daerah terpolusi karena memiliki kemampuan adaptasi yang baik terhadap lingkungan yang terpolusi. Menurut Triana (2012), udang selalu mencari makan di dasar air (detrivorus) yakni pada sedimen, sehingga Penaeus merguiensis diduga dapat dijadikan sebagai salah satu indikator yang baik untuk mengetahui tingkat pencemaran yang terjadi di dalam perairan.

Beberapa hasil penelitian telah dilakukan di Perairan Teluk Kelabat, seperti konsentrasi logam berat di air, sedimen dan biota (Arifin, 2011), kondisi oseanografis perairan (Sachoemar et al., 2007), dan tingkat daya racun sedimen (Hindarti et al., 2008). Penelitian ini bertujuan untuk mengetahui kandungan logam berat $\mathrm{Pb}$ dan Cu (air, sedimen, dan Penaeus merguiensis) serta mengukur kemampuan Penaeus merguiensis dalam mengakumulasi logam berat $\mathrm{Pb}$ dan $\mathrm{Cu}$.

\section{MATERI DAN METODE}

Pengambilan sampel dilakukan di Perairan Teluk Kelabat Bagian Dalam, Kecamatan Parittiga (Gambar 1). Pengukuran tekstur sedimen dilakukan di Laboratorium Manajemen Sumberdaya Perairan, Universitas Bangka Belitung. Analisis kandungan logam berat $\mathrm{Pb}$ dan $\mathrm{Cu}$ dalam air, sedimen, dan Penaeus merguiensis dilakukan di Laboratorium PT. TININDO Inter Nusa, Pangkalpinang. 
Pengambilan sampel air menggunakan water sampler, sampel sedimen menggunakan ekman grab, dan sampel Penaeus merguiensis menggunakan pukat. Contoh air dimasukkan ke dalam botol polietilen, sedangkan contoh sedimen dan Penaeus merguiensis masing-masing dimasukkan ke dalam wadah polystyrene. Ketiga contoh sampel tersebut selanjutnya dimasukkan dalam cool box (Zhang, 2007).

Preparasi sampel air yaitu sebanyak 50 $\mathrm{mL}$ sampel air dimasukkan ke dalam gelas piala $100 \mathrm{~mL}$ dan ditambahkan $5 \mathrm{~mL} \mathrm{\textrm {HNO } _ { 3 }}$ pekat, kemudian tutup dengan kaca arloji. Sampel air dipanaskan sampai sisa volumenya $15-20 \mathrm{~mL}$. Setelah itu kaca arloji dibilas dan air bilasannya dimasukan ke dalam gelas piala. Kemudian sampel air dipindahkan ke dalam labu ukur $50 \mathrm{~mL}$ dan ditambahkan air akuades sampai tepat tanda batas lalu dihomogenkan. Selanjutnya dibaca serapannya dengan menggunakan alat AAS dan dicatat hasilnya (SNI, 2009).

Preparasi sampel sedimen dilakukan dengan cara sedimen dikering udarakan pada suhu ruang, kemudian dihaluskan dengan digerus kemudian dihomogenkan. Sedimen yang sudah dihomogenkan ditimbang sebanyak $\pm 3 \mathrm{~g}$, kemudian dimasukkan ke dalam Erlenmeyer dan ditambahkan $25 \mathrm{~mL}$ air suling. Sedimen tersebut ditambahkan lagi 5-10 mL asam nitrat, $\mathrm{HNO}_{3}$ pekat dan aduk hingga bercampur rata. Campuran tersebut dipanaskan sampai volumenya $\pm 10 \mathrm{~mL}$. Setelah itu ditambahkan $5 \mathrm{~mL}$ asam nitrat ( $\mathrm{HNO}_{3}$ pekat) dan $1 \mathrm{~mL}$ sampai dengan $3 \mathrm{~mL}$ asam perklorat $\left(\mathrm{HClO}_{4}\right.$ pekat). Contoh uji dipanaskan kembali pada penangas listrik sampai timbul asap putih dan larutan contoh uji menjadi jernih. Filtrat contoh uji siap diukur ke dalam Spektrofotometer Serapan Atom (SSA) (SNI, 2004).

Preparasi sampel Penaeus merguiensisdiawali dengan menghaluskan sampel Penaeus merguiensis dengan menggunakan blender hingga menjadi partikel kecil dan diletakkan di wadah polystyrene. Sampel tersebut (daging) ditimbang sebanyak 1-2 g ke dalam tabung sampel (vessel) dan dicatat beratnya (W). Masing-masing sampel ditambahkan $0,2 \mathrm{~mL}$ larutan standar $\mathrm{Pb} \quad 1 \mathrm{mg} / \mathrm{L}$ atau larutan standar $\mathrm{Pb} 200 \mu \mathrm{g} / \mathrm{L}$ sebanyak $1 \mathrm{~mL}$. Sampel ditambahkan secara berurutan 5-10 $\mathrm{mL} \mathrm{HNO}_{3}$ $65 \%$ dan $2 \mathrm{~mL} \mathrm{H}_{2} \mathrm{O}_{2}$. Dekstruksi dilakukan dengan mengatur program microwave.

Hasil dekstruksi dipindahkan ke labu takar $50 \mathrm{~mL}$ dan ditambahkan larutan matrik modifier, kemudian tepatkan sampai tanda batas dengan air deionisasi dan siap dianalisa menggunakan AAS (SNI, 2011).

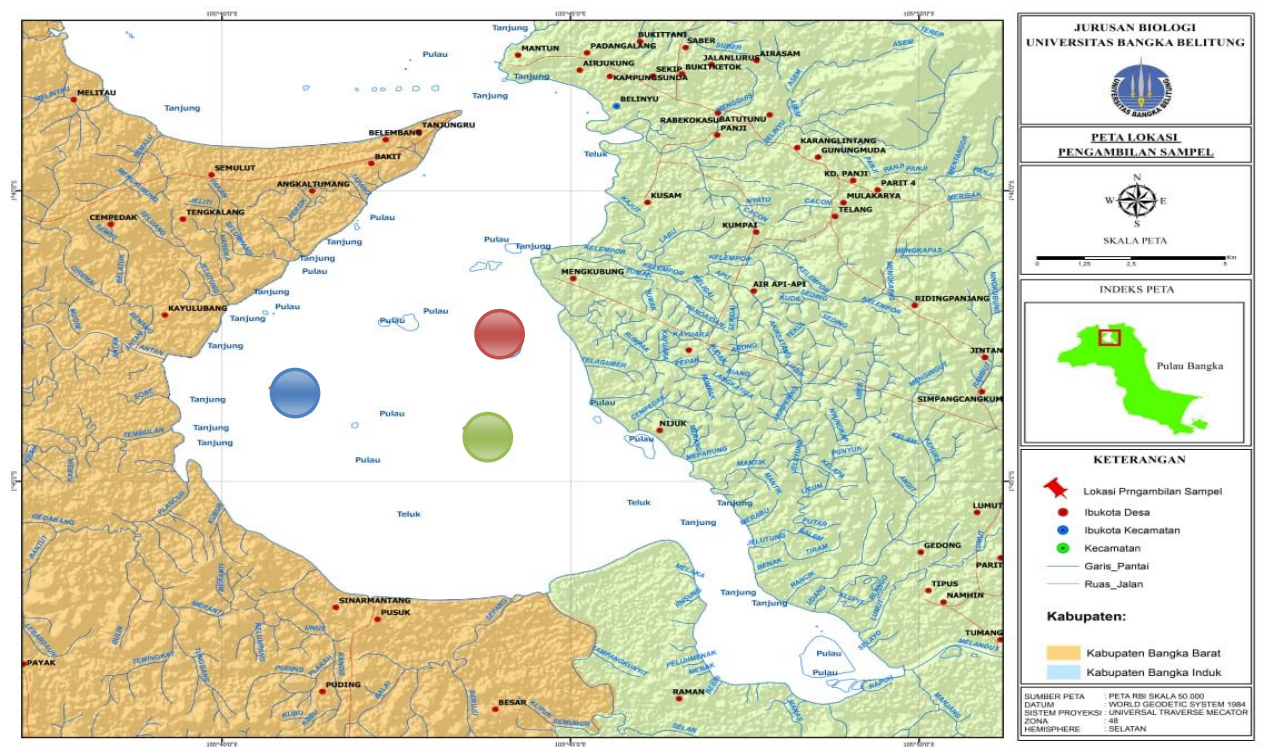

Gambar 1. Peta lokasi penelitian

Keterangan: $\odot=$ stasiun $1, \odot=\operatorname{stasiun} 2, \ominus=\operatorname{stasiun} 3$ 


\section{Analisis Data}

\begin{abstract}
Konsentrasi logam berat $\mathrm{Pb}$ dan $\mathrm{Cu}$ pada sampel diperoleh dengan menggunakan rumus dari SNI (2009). Untuk menghitung kemampuan Penaeus merguiensis dalam mengakumulasi logam berat $\mathrm{Pb}$ dan $\mathrm{Cu}$, melalui tingkat Faktor Biokonsentrasi (FBK) yang merupakan rasio antara nilai konsentrasi logam pada Penaeus merguiensis $\left(\mathrm{C}_{\mathrm{f}}\right)$ dan konsentrasi logam pada air atau sedimen (Cw) (Sari et al.,2017).
\end{abstract}

\section{HASIL DAN PEMBAHASAN}

Hasil pengukuran parameter fisika dan kimia perairan (Tabel 1) menunjukkan bahwa nilai rata-rata semua parameter yang diukur belum melampaui baku mutu yang telah ditetapkan oleh Keputusan Menteri Lingkungan Hidup No.51 Tahun 2004. Hal ini memberikan gambaran bahwa kualitas Perairan Teluk Kelabat bagian dalam dilihat dari segi fisika dan kimianya masih layak digunakan untuk kegiatan perikanan

Sedimen perairan terdiri dari berbagai tipe substrat dengan ukuran butiran yang berbeda karena perbedaan proses pembentukannya. Tipe sedimen yang didapatkan secara umum didominasi oleh lumpur (Tabel 2). Menurut Gemilang et al., (2017), perbedaan dominasi tekstur sedimen mencirikan proses pengendapan atau pembentukan sedimen yang disebabkan oleh perbedaan arus.

Perairan dengan kecepatan arus relatif kuat kurang mampu mengendapkan partikel relatif kecil dan sebaliknya, partikel dengan ukuran relatif besar seperti pasir akan dapat dengan mudah diendapkan daripada ukuran relatif kecil seperti lempung dan lanau. Kondisi variabilitas dan pola adveksi air laut memberikan peran penting dan diduga sebagai faktor penyebab terjadinya perbedaan komposisi tekstur yang ada di wilayah penelitian.

\section{Kandungan Logam Berat $\mathrm{Pb}$ dan $\mathrm{Cu}$ dalam Air Laut}

Kandungan logam berat $\mathrm{Pb}$ dan $\mathrm{Cu}$ dalam air laut berkisar rata-rata $\mathrm{Pb}$ yaitu
0,1042-0,1748 mg/L dan Cu yaitu0,000013$0,000021 \mathrm{mg} / \mathrm{L}$ (Tabel 3). Kandungan logam berat $\mathrm{Pb}$ dan $\mathrm{Cu}$ tertinggi terdapat pada stasiun 3 dengan nilai $\mathrm{Pb}$ sebesar $0,1748 \mathrm{mg} / \mathrm{L}$ dan Cu $0,000021 \mathrm{mg} / \mathrm{L}$. Hal ini disebabkan karena stasiun 3 merupakan daerah Sungai Antan yang berdekatan dengan aktivitas penambangan timah tradisional dengan intensitas paling tinggi. Menurut Nuraini et al., (2017), tinggi rendahnya kandungan logam berat di perairan disebabkan oleh jumlah masukan limbah logam berat tersebut ke perairan. Aktivitas penambangan timah menghasilkan limbah berupa tailing. Limbah sisa penambangan timah mengandung logam berat ikutan dari timah yang tidak dimanfaatkan tetapi dibuang ke perairan. Penelitian Prianto dan Husnah (2009) menyatakan bahwa Perairan Pulau Bangka memiliki kandungan logam berat dari sisa penambangan timah (tailing) seperti $\mathrm{Sn}, \mathrm{Pb}$, $\mathrm{Cr}, \mathrm{Cu}$, dan Cd.

Parameter fisika dan kimia perairan juga akan mempengaruhi tinggi rendahnya kandungan logam berat dalam air (Nuraini et al., 2017). Suhu air akan mendukung tingginya kelarutan logam berat dalam air.Hasil pengukuran rata-rata di lapangan suhu air laut berkisar antara $29,83-31,83^{\circ} \mathrm{C}$. Nilai suhu yang diperoleh masih dalam batas alami (Kepmen LH No.51, 2004). Kenaikan suhu air dapat menguraikan derajat kelarutan mineral sehingga kelarutan logam berat $\mathrm{Pb}$ dan $\mathrm{Cu}$ pada air tinggi. Hasil pengukuran $\mathrm{pH}$ air rata-rata cenderung rendah (pH asam) yaitu antara 6,4-6,7. $\mathrm{pH}$ air berpengaruh terhadap kesadahan kadar logam berat dalam air, apabila $\mathrm{pH}$ air rendah akan berakibat terjadinya proses korosif sehingga menyebabkan larutnya logam berat dalam air. $\mathrm{Ph}<7$ dapat melarutkan logam (Supriyantini et al., 2015).

Tabel 2. Hasil pengukuran rata-rata tekstur sedimen laut

\begin{tabular}{|c|c|c|c|c|}
\hline \multirow{2}{*}{ Stasiun } & \multicolumn{3}{|c|}{ Tekstur Sedimen (\%) } & \multirow{2}{*}{$\begin{array}{c}\text { Tipe } \\
\text { Sedimen }\end{array}$} \\
\hline & Pasir & Lumpur & Debu & \\
\hline 1 & 0,1 & 92,29 & 7,61 & Lumpur \\
\hline 2 & 0,54 & 95,74 & 3,72 & Lumpur \\
\hline 3 & 1,07 & 95,61 & 3,32 & Lumpur \\
\hline
\end{tabular}


Tabel 1. Nilai rata-rata parameter fisika dan kimia Perairan Teluk Kelabat bagian dalam

\begin{tabular}{lcccc}
\hline \multirow{2}{*}{ Parameter } & \multicolumn{3}{c}{ Stasiun } & Baku Mutu* \\
\cline { 2 - 4 } & 1 & 2 & 3 & Balami \\
\hline Suhu $\left({ }^{\circ} \mathrm{C}\right)$ & 29,83 & 31,5 & 31,83 & alami \\
Salinitas $(\% \circ)$ & 22,67 & 20 & 22 & $7-8,5$ \\
$\mathrm{pH}$ & 6,7 & 6,4 & 6,4 & Coral: $>5$ \\
Kecerahan $(\mathrm{m})$ & 1,35 & 1,83 & 1,39 & Mangrove: - Lamun: $>3$ \\
\hline
\end{tabular}

*Berdasarkan Keputusan Menteri Lingkungan Hidup No.51 Tahun 2004 (Biota Laut)

Hasil penelitian ini memiliki perbedaan dengan penelitian yang dilakukan Yayu dan Permanawati (2015) di Perairan Pantai Timur Pulau Rote. Hasil penelitian Yayu dan Permanawati menunjukkan bahwa kandungan logam berat $\mathrm{Pb}$ dan $\mathrm{Cu}$ rata-rata $<0,008$. Hal ini disebabkan karena Perairan Pantai Timur Pulau Rote merupakan perairan yang masih alami dan sedikit terdapat bahan pencemar.Kandungan logam berat Pbdi Perairan Teluk Kelabat bagian dalam telah melampaui baku mutu kriteria kualitas air bagi perlindungan biota laut yaitu sebesar $(0,008 \mathrm{mg} / \mathrm{L})$, sedangkan logam berat $\mathrm{Cu}$ belum melampaui baku mutu yang telah ditetapkan oleh KepMen LH No.51 tahun 2004 sebesar $0,008 \mathrm{mg} / \mathrm{L}$.

\section{Kandungan Logam Berat $\mathrm{Pb}$ dan $\mathrm{Cu}$ dalam Sedimen}

Kandungan logam berat $\mathrm{Pb}$ dan $\mathrm{Cu}$ berturut-turut dalam sedimen laut berkisar rata-rata $7,15-7,73 \mathrm{mg} / \mathrm{kg}$ dan0,00160-0,00219 $\mathrm{mg} / \mathrm{kg}$ (Tabel 4). Kandungan logam berat Pb dan Cu rata-rata tetinggi terdapat pada stasiun 1 dan terendah terdapat pada stasiun 2. Tingginya konsentrasi Logam Berat Pbpada stasiun 1 dikarenakan stasiun ini memiliki persentase kandungan sedimen halus (gabungan debu dan liat) yang lebih tinggi $(99,9 \%)$ daripada stasiun $2(99,46 \%)$ dan 3 (98,93 \%). Berdasarkan Maslukah (2013), umumnya sedimen yang mempunyai ukuran sedimen yang lebih halus dan mempunyai banyak kandungan organik mengandung konsentrasi logam berat yang lebih besar daripada sedimen yang mempunyai tipe ukuran butiran sedimen berukuran besar.

Kandungan logam berat $\mathrm{Pb}$ dan $\mathrm{Cu}$ rata-rata dalam sedimen di semua stasiun memiliki nilai yang lebih tinggi dibandingkan kandungan logam dalam air. Hal ini disebabkan karena logam berat dalam air mudah terserap dan tertimbun dalam fitoplankton yang merupakan titik awal dari rantai makanan, sedangkan logam berat yang terikat dalam sedimen relatif sukar untuk lepas kembali larut dalam air. Sedimen merupakan tempat penimbunan segala pencemar yang terdapat pada perairan melalui proses pengikatan dengan bahan tersuspensi, terkoagulasi dan mengendap (sinking) dan menjadi tertimbun pada sedimen (Siregar dan Edward, 2010).

Hasil penelitian ini memiliki nilai yang lebih tinggi dibandingkan penelitian Nasution dan Siska (2011) yaitu sebesar $3 \mathrm{mg} / \mathrm{kg}$. Perbedaan hasil penelitian ini disebabkan oleh perbedaan kondisi oseanografis perairan itu sendiri. Kandungan logam berat $\mathrm{Pb}$ dan $\mathrm{Cu}$ dalam sedimen belum melebihi ambang batas menurut Canadian Environmental Quality Guide Lines (2002) yaitu sebesar $\mathrm{Pb} 30,2 \mathrm{mg} / \mathrm{kg}$ dan $\mathrm{Cu} 18,7$ $\mathrm{mg} / \mathrm{kg}$.

\section{Kandungan Logam Berat $\mathrm{Pb}$ dan $\mathrm{Cu}$ dalam Penaeus merguiensis}

Hasil penelitian menunjukkan bahwa kandungan logam berat $\mathrm{Pb}$ dan $\mathrm{Cu}$ rata-rata dalam Penaeus merguiensisberkisar antara $\mathrm{Pb}(1,34-1,54 \mathrm{mg} / \mathrm{kg})$ dan $\mathrm{Cu}(0,00030-0,00045$ $\mathrm{mg} / \mathrm{kg}$ ) (Tabel 5). Kandungan logam berat $\mathrm{Pb}$ dan Cu rata-rata dalam Penaeus merguiensis lebih rendah daripada sedimen dan lebih tinggi daripada air. Hal ini sesuai dengan penelitian yang dilakukan oleh Budiarti et al. (2010) yang menyatakan bahwa hasil penelitian di muara sungai maupun di perairan pantai menunjukkan bahwa kandungan logam berat dari yang terkecil hingga yang terbesar secara berurutan yaitu air, udang, sedimen. Hal ini disebabkan karena $\mathrm{Pb}$ dan $\mathrm{Cu}$ merupakan logam berat 
yang pada akhirnya mengendap di sedimen dalam jumlah yang lebih besar dibandingkan dalam air.

Menurut Novianto et al., (2012), Kadar $\mathrm{Pb}$ dan $\mathrm{Cu}$ akan terakumulasi dalamtubuh Penaeus merguiensis melalui absorbsi logam yangmasuk ke dalam insang ataupun saat pergantiankulit (moulting) dan masuk ke dalam saluranpencernaan melalui aktivitas makan. Prosesbioakumulasi logam dalam jaringan udang melalui rantai makanan serta tingginya proses pengambilan logam $\mathrm{Pb}$ dan Cu dari perairan atau sedimen menyebabkan tingginya konsentrasi $\mathrm{Pb}$ dan Cu dalam tubuh Penaeus merguiensis.

Penaeus merguiensis yang mengandung logam berat $\mathrm{Pb}$ dan $\mathrm{Cu}$, jika dikonsumsi oleh manusia secara terus menerus, dapat menambah konsentrasi $\mathrm{Pb}$ dan Cu dalam tubuh sehingga dapat menyebabkan beberapa penyakit seperti kerusakan ginjal, degeneratif pada otak, dan sirosis pada hati. Berdasarkan hal tersebut, konsumsi Penaeus merguiensissecara berlebihan dan dalam waktu yang lama dapat menyebabkan berbagai macam gangguan pada sistem jaringan tubuh (Fitriani et al., 2014).
Hasil penelitian ini memiliki perbedaan dengan penelitian yang dilakukan oleh Lestari et al., (2018) di Perairan Pelabuhan Pontianak. Kandungan logam berat dalam penelitian ini memiliki nilai yang lebih tinggi dibandingkan penelitian Lestari et al., (2018) yang mana nilai rata-rata logam $\mathrm{Pb}$ sebesar $0,039 \mathrm{mg} / \mathrm{kg}$. Perbedaan kedua hasil penelitian ini disebabkan karena Perairan Teluk Kelabat bagian dalam memiliki bahan pencemar yang lebih tinggi berupa limbah tailing dibandingkan Perairan Pelabuhan Pontianak. Kandungan logam berat $\mathrm{Pb}$ dan Cu dalam Penaeus merguiensis belum melampaui baku mutu yang ditetapkan oleh Food and Agricultural Organization (FAO) yaitu sebesar $1,5 \mathrm{mg} / \mathrm{kg}$.

\section{Nilai Faktor Biokonsentrasi (FBK) $\mathrm{Pb}$ dan $\mathrm{Cu}$ pada Penaeus merguiensis}

Hasil penelitian menunjukkan bahwa nilai FBK Penaeus merguiensis terhadap sedimen maupun air rata-rata nilainya rendah untuk $\mathrm{Pb}$ sedimen $(0,17-0,21)$, $\mathrm{Cu}$ sedimen $(0,18-0,20), \mathrm{Pb}$ air $(9,06-14,48)$, dan Cu air (18,07-34,70) (Tabel 6). Dalam penelitian ini terdapat 2 nilai FBK yaitu FBKo-s yang merupakan perbandingan konsentrasi logam di dalam biota dengan konsentrasi

Tabel 3. Rata-rata kandungan logam berat Pb dan $\mathrm{Cu}$ dalam air laut

\begin{tabular}{ccccc}
\hline \multirow{2}{*}{ Stasiun } & \multicolumn{2}{c}{ Konsentrasi Rata-rata $(\mathrm{mg} / \mathrm{L})$} & \multicolumn{2}{c}{ Baku Mutu* $(\mathrm{mg} / \mathrm{L})$} \\
\cline { 2 - 5 } & $\mathrm{Pb}$ & $\mathrm{Cu}$ & $\mathrm{Pb}$ & $\mathrm{Cu}$ \\
\hline 1 & $0,1226 \pm 0,0201$ & $0,000013 \pm 0,0000030$ & & \\
2 & $0,1042 \pm 0,0072$ & $0,000013 \pm 0,0000025$ & 0,008 & 0,008 \\
3 & $0,1748 \pm 0,0306$ & $0,000021 \pm 0,0000030$ & & \\
\hline *Berdasarkan Keputusan Menteri Lingkungan Hidup No.51 Tahun 2004 & &
\end{tabular}

Tabel 4. Rata-rata kandungan logam berat $\mathrm{Pb}$ dan $\mathrm{Cu}$ dalam sedimen laut

\begin{tabular}{ccclc}
\hline \multirow{2}{*}{ Stasiun } & \multicolumn{2}{c}{ Konsentrasi Rata-rata $(\mathrm{mg} / \mathrm{kg})$} & \multicolumn{2}{c}{ Baku Mutu* $(\mathrm{mg} / \mathrm{kg})$} \\
\cline { 2 - 5 } & $\mathrm{Pb}$ & $\mathrm{Cu}$ & $\mathrm{Pb}$ & $\mathrm{Cu}$ \\
\hline 1 & $7,73 \pm 0,41$ & $0,00219 \pm 0,00017$ & \\
2 & $7,15 \pm 0,64$ & $0,00160 \pm 0,00031$ & 30,2 & 18,7 \\
3 & $7,16 \pm 0,55$ & $0,00215 \pm 0,00070$ & & \\
\hline
\end{tabular}

*Berdasarkan Canadian Environmental Quality Guide Lines (2002)

Tabel 5. Rata-rata kandungan logam berat $\mathrm{Pb}$ dan $\mathrm{Cu}$ dalam Penaeus merguiensis

\begin{tabular}{ccccc}
\hline \multirow{2}{*}{ Stasiun } & \multicolumn{2}{c}{ Konsentrasi Rata-rata $(\mathrm{mg} / \mathrm{kg})$} & \multicolumn{2}{c}{ Baku Mutu* $(\mathrm{mg} / \mathrm{kg})$} \\
\cline { 2 - 5 } & $\mathrm{Pb}$ & $\mathrm{Cu}$ & $\mathrm{Pb}$ & $\mathrm{Cu}$ \\
\hline 1 & $1,34 \pm 0,12$ & $0,00045 \pm 0,00010$ & 10 \\
2 & $1,51 \pm 0,10$ & $0,00030 \pm 0,00013$ & 1,5 & \\
3 & $1,54 \pm 0,07$ & $0,00039 \pm 0,00016$ & &
\end{tabular}


Tabel 6. Nilai FBK Penaeus merguiensis terhadap sedimen dan air

\begin{tabular}{|c|c|c|c|c|}
\hline \multirow{3}{*}{ Stasiun } & \multicolumn{4}{|c|}{ Rata-rata } \\
\hline & \multicolumn{2}{|c|}{$\mathrm{Pb}$} & \multicolumn{2}{|c|}{$\mathrm{Cu}$} \\
\hline & Sedimen & Air & Sedimen & Air \\
\hline 1 & $0,17 \pm 0,02$ & $11,13 \pm 1,70$ & $0,20 \pm 0,05$ & $34,70 \pm 3,96$ \\
\hline 2 & $0,21 \pm 0,03$ & $0,18 \pm 0,57$ & $0,18 \pm 0,08$ & $24,16 \pm 14,74$ \\
\hline 3 & $0,21 \pm 0,02$ & $18,07 \pm 2,25$ & $0,19 \pm 0,08$ & $18,07 \pm 5,27$ \\
\hline
\end{tabular}

logam di dalam sedimen dan FBKo-w merupakan perbandingan konsentrasi logam di dalam biota dengan konsentrasi logam di dalam air. Berdasarkan analisis konsentrasi logam di air maupun di sedimen, maka diperoleh perbandingan FBKo-w dan FBKo-s. Nilai FBKo-w cenderung lebih tinggi daripada FBKo-s untuk kedua logam yang dihitung. Hal ini berarti bahwa Penaeus merguiensislebih banyak terpapar logam yang terlarut di badan air daripada yang terlepas dari sedimen (Sari et al., 2017).

Hasil peneltian ini memiliki perbedaan dengan penelitian yang dilakukan Sari et al., (2017). Hasil penelitian sari menunjukkan bahwa rata-rata nilai FBK pada udang terhadap air sebesar 83. Berdasarkan hasil perhitungan nilai biokonsentrasi, maka dapat ditarik kesimpulan bahwa Penaeus merguiensis memiliki kemampuan mengakumulasi logam berat dalam kategori rendah (FBK < 250). Menurut Hidayah et al. (2014), semakin tinggi nilai FBK pada suatu organisme menunjukkan semakin tinggi organisme tersebut mengakumulasi logam berat.

\section{KESIMPULAN}

Berdasarkan penelitian yang telah dilakukan disimpulkan bahwa kandungan Logam Berat dalam air, sedimen, dan Penaeus merguiensis untuk $\mathrm{Pb}$ dan $\mathrm{Cu}$ ratarata berturut-turut berkisar antara air $(0,1042$ $0,1748 \mathrm{mg} / \mathrm{L})$ dan $(0,000013-0,000021 \mathrm{mg} / \mathrm{L})$, sedimen $(7,15-7,73 \mathrm{mg} / \mathrm{kg})$ dan $(0,0016$ $0,00219 \mathrm{mg} / \mathrm{kg})$, Penaeus merguiensis (1,34$1,54 \mathrm{mg} / \mathrm{kg})$ dan $(0,0003-0,00045 \mathrm{mg} / \mathrm{kg})$. Kemampuan Penaeus merguiensis dalam mengakumulasi Logam Berat $\mathrm{Pb}$ dan Cu ratarata niilai rendah baik terhadap air $(15,83)$ maupun terhadap sedimen $(0,19)$. Nilai Faktor Biokonsentrasi tersebut di bawah 250 (FBK< 250) sehingga masuk dalam kategori rendah.
Penaeus merguiensis lebih banyak terpapar logam berat yang terlarut dalam air daripada yang terlepas dari sedimen.

\section{DAFTAR PUSTAKA}

Arifin, Z. 2011. Konsentrasi Logam Berat Di Air, Sedimen Dan Biota Di Teluk Kelabat, Pulau Bangka. J. Ilmu Tek. Kel. Trop., 3(1):104-114

Budiarti, A., Kusreni \& Musinah, S. 2010. Analisis Kandungan Logam Berat Timbal (Pb) Dan Kadmium (Cd) dalam Udang Putih (Litopenaeus vannamei) yang diperoleh dari Muara Sungai Banjir Kanal Barat dan Perairan Pantai Kota Semarang. Prosiding Seminar Nasional Sains dan Teknologi. Fakultas Teknik Universitas Wahid Hasyim Semarang

Canadian Environmental Quality Guidelines. 2002. Summary of Existing Canadian Environmental Quality Guidelines. Winnipeg: Canadian Environmental Quality Guidelines.

Fitriani, A., Sulfikar \& Dini, I. 2015. Analisis Kandungan Logam Timbal (Pb) pada Sedimen dan Udang Windu (Penaeus monodon) di Pantai Biringkassi Kecamatan Bungoro Kabupaten Pangkep. Sainsmat, 3(2):

Food and Agricultural Organization (FAO). 1983. Compilation of legal limits for hazardous substances in Fish and Fishery Products. Rome: FAO Fishery Circular No 764: Food and Agriculture Organization

Gemilang, W.A., Wisha, U.J. \& Rahmawan, G.A., 2017. Distribusi sedimen dasar sebagai identifikasi erosi pantai di Kecamatan Brebes menggunakan analisis granulometri. J. Kel. : Ind. J. Mar. Sci. Technol. 10(1):54-66.

Hindarti, D., Arifin, Z., Puspitasari, R. \& Rochayatun, E. 2008. Sediment contaminant and toxicity in Klabat Bay, 
Bangka Belitung, Indonesia. Mar. Res. Ind. 33(2):203-212.

Hukom, F.D. 2010. Keanekaragaman Dan Kelimpahan Sumberdaya Ikan Di Teluk Klabat, Perairan Bangka Belitung. J. Iktiologi Ind., 10(1):1 1-23

Keputusan Menteri Negara Lingkungan HIdup: No.51 Tahun 2004 tentang baku mutu air laut untuk biota laut, Jakarta

Lestari, D.A., Junardi \& Rousdy, D.W. 2018. Konsentrasi Timbal (Pb) pada Daging Udang Hasil Tangkapan Nelayan di Desa Jungkat Kecamatan Siantan Kabupaten Mempawah. Protobiont 7(1):20-24

Maslukah, L. 2013. Hubungan antara Konsentrasi Logam Berat $\mathrm{Pb}, \mathrm{Cd}, \mathrm{Cu}, \mathrm{Zn}$ dengan Bahan Organik dan Ukuran Butir dalam Sedimen di Estuari Banjir Kanal Barat, Semarang. Bul. Oseano. Mar. 2:5562

Nasution, S. \& Siska, M. 2011. Kandungan Logam Berat Timbal (Pb) Pada Sedimen dan Siput (Strombus canarium) di Perairan PantaiPulau Bintan. J. IImu Lingkungan. 5(2):82-93

Novianto, R.T.W.D., Rachmadiarti, F. \& Raharjo. 2012. Analisis Kadar Timbal (Pb) dan Kadmium (Cd) pada Udang Putih (Penaeus marguiensis) di Pantai Gesek Sedati Sidoarjo. Lentera Bio. 1 (2):63-66

Nuraini, R.A.T., Indrawati, H. \& Maulana, I.R. 2017. Analisis Kandungan Logam Berat Kromium (Cr) Pada Air, Sedimen Dan Kerang Hijau (Perna viridis) Di Perairan Tri mulyo Semarang. Jurnal Kelautan Tropis 20(1):48-55

Prianto, \& Husnah. 2009. Penambangan Timah Inkonvensional: Dampaknya Terhadap Kerusakkan Biodiversitas Perairan Umum Di Pulau Bangka. Bawal : Widya Riset Perikanan Tangkap, 2(5):193-198

Sachoemar, S.I., Kristijono, A. \& Yanagi, Y. 2007. Oceanographic chracteristics of Klabat Bay, Bangka Island, Indonesia. Mar. Res. Ind. 32(2):49-54.

Said, I., Jalaluddin, N.M., Upe, A. \& Wahab, W.A. 2009. Akumulasi Logam Berat Krom Dan Timbal Dalam Sedimen Estuaria Sungai Matangpondo Palu. J. Mat Sains Media Eksakta, 5(2):63-68.

Sari, Y.P.P.R., Rumhayati, B. \& Srihardyastutie, A. 2017. Bioaccumulation of Heavy Metals $\mathrm{Pb}, \mathrm{Cd}$ And $\mathrm{Zn}$ on Bentos in the
Estuary of Porong River Sidoarjo. Natural $B, 4(1): 1-10$

Selpiani, L., Umroh \& Rosalina, D. 2015. Konsentrasi Logam Berat (Pb, Cu ) Pada Kerang Darah (Anadara Granosa) di Kawasan Pantai Keranji Bangka Tengahdan Pantai Teluk Kelabat Bangka Barat. Oseatek Vol. 9 (01)

Simanjuntak, M. 2007. Oksigen Terlarut dan Apparent Oxygen Utilization di Perairan Teluk Klabat, Pulau Bangka.IImu Kelautan : Ind. J. Mar. Sci. 12(2):59-66

Siregar, Y.I., Edward, J. 2010. Faktor Konsentrasi $\mathrm{Pb}, \mathrm{Cd}, \mathrm{Cu}, \mathrm{Ni}, \mathrm{Zn}$ dalam Sedimen PerairanPesisir Kota Dumai. Maspari J. 1 (1):1-10

SNI. 2004. Cara Uji Timbal (Pb) Secara Destruksi Asam dengan Spektrofotometer Serapan Atom (SSA). Jakarta: Badan Standardisasi Nasional

SNI. 2009. Cara Uji Timbal (Pb) Secara Spektrofotometri Serapan Atom (SSA) Nyala. Jakarta: Badan Standardisasi Nasional

SNI. 2011. Cara Uji Kimia-bagian 5: Penentuan Kadar Logam Berat Timbal dan Kadmium pada produk perikanan. Jakarta: Badan Standardisasi Nasional

Suhendar, Sachoemar \& Kristijono, A. 2005. Evaluas iKondisi Lingkungan Perairan Estuaria Teluk Kelabat, Bangka pada Musim Timur. J. Tek. Ling. 6(3):438-445

Supriyantini, E., \& Endrawati, H. 2015. Kandungan Logam Berat Besi (Fe) Pada Air, Sedimen, Dan Kerang Hijau (Perna viridis) Di Perairan Tanjung Emas Semarang. J. Kel. Trop. 18(1):38-45

Triana, L., Nurjazuli \& Endah, N. 2012. Analisis cemaran logam berat merkuri pada air dan udang di sungai Mandor kecamatan Mandor kabupaten Landak. J. Kes. Ling. Ind. 11 (2):144-152.

Yayu, G., \& Permanawati, Y. 2015. Kandungan Logam Berat (Cd, Cu, Pb, dan Zn) dalam Air Laut Di Perairan Pantai Timur Pulau Rote.Geologi Kel. 13(2):99-107

Zhang, C. 2007. Fundamental of Environmental Sampling and Analysis. United Statet of America: John Wiley Publication 